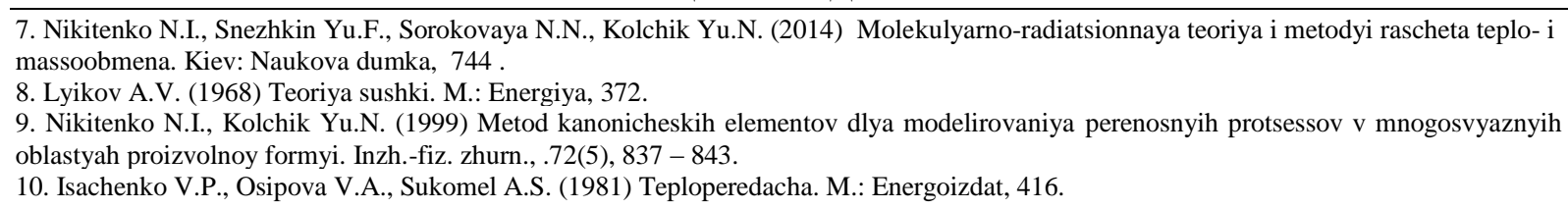

\title{
ДОСЛІДЖЕННЯ ГІДРОДИНАМІЧНИХ ХАРАКТЕРИСТИК ЕЛЕМЕНТІВ ЗАХИСТУ ХАРЧОВИХ ВИРОБНИЦТВ
}

\author{
Рябова І.Б. ${ }^{1}$, к.т.н., доцент, Петухова О.А. ${ }^{2}$, к.т.н., доцент, \\ Горносталь С.А. ${ }^{2}$, к.т.н., Щербак С.М. ${ }^{2}$ \\ ${ }^{1}$ Національний технічний університет «ХПІ», м. Харків \\ ${ }^{2}$ Національний університет цивільного захисту України, м. Харків
}

\begin{abstract}
Анотація. Важливою складовою собівартості продукиї харчових виробництв є елементи забезпечення їх безпечного виробництва, одним з яких являється внутрішній протипожежний водопровід, який обов'язковий для встановлення в приміщеннях харчових виробниитв з відповідною категорією за вибухопожежною та пожежною небезпекою, ступенем вогнестійкості та об'ємом виробничого корпусу. 3 введенням в дію ДБН В 2.5-64:2012 «Внутрішній водопровід та каналізація» кожна шафа окрім встановленого в ній пожежного кран-комплекту діаметром 50 або 65 мм, обов'язково комплектується додатковим пожежним кран-комплектом діаметром 25 або 33 мм, який призначений для швидкого введення вогнегасної речовини в початковій стадії розвитку пожежі, а тому забезпечує зниження збитків від неї. Додаткові кран-комплекти комплектуються рукавом (довжина рукава - до 30 м, діаметр рукава - 25 мм або 33 мм, тип рукава - напівжорсткий) та розпорошувачем (діаметр випускного отвору розпорошувача від 4 до 12 мм). До переваг таких пристроїв відносять невеликі габарити, застосування спеціальних насадок розпорошувача дозволяє створювати дрібнодисперсний струмінь води, який не пошкоджує оточуючи речи та обладнання, гнучкий рукав комплекту дозволяє обійти технологічні установки, щуо зустрічаються на шляху, установка перекривного пристрою дозволяє перервати роботу в будь-який момент і відновити ї̈ за необхідності, вартість вогнегасної речовини - води, як $і$ самої установки - невелика. В залежності від умов використання додаткового пожежного кран-комплекту різні характеристики його складових можуть забезпечити підвищення або зниження ефективності його роботи. Тому запропоновано спосіб визначення характеристик складових додаткового пожежного кран-комплекту для конкретних умов його експлуатаиії. Вірний вибір параметрів складових дозволить з урахуванням гідродинамічних характеристик системи, щу забезпечує роботу таких пристроїв, з найменшими економічними втратами забезпечити успішне гасіння пожежі та знизити збитки від неї.
\end{abstract}

Ключові слова: пожежний кран-комплект, тиск, витрати води, рукав, розпорошувач.

\section{STUDYING THE HYDRODYNAMIC CHARACTERISTICS OF PROTECTION ELEMENTS IN FOOD PRODUCTION}

\author{
Rjabova I.B. ${ }^{1}$, PhD, associate professor, Petukhova O.A. ${ }^{2}$, PhD, associate professor, \\ Gornostal S.A. ${ }^{2}$, PhD, Shcherbak S.M. ${ }^{2}$ \\ ${ }^{1}$ National Technical University «KPI», Kharkiv \\ ${ }^{2}$ National University of Civil Protection of Ukraine, Kharkiv
}

\begin{abstract}
An important component of the cost of food products is the elements of ensuring their safe production, one of which is the internal fire water supply, which is obligatory for installation in the premises of food production enterprises with the appropriate category for fire and fire hazard, fire resistance and the volume of the production building. With the introduction of the DBN V 2.5-64:2012 "Internal plumbing and sewage system", each cabinet, except for installed fire faucet with a diameter of 50 or $65 \mathrm{~mm}$, necessarily completes an additional fire faucet with a diameter of 25 or $33 \mathrm{~mm}$, which is designed for the rapid introduction of extinguishing agent in the initial stage of the development of the fire, and therefore provides a reduction of losses from it. Additional fire faucets are completed with a sleeve (length of the sleeve - up to $30 \mathrm{~m}$, diameter of the sleeve - 25 mm or $33 \mathrm{~mm}$, type of sleeve - semi-rigid) and the sprayer (diameter of the outlet of the sprayer from 4 to 12 $\mathrm{mm})$. The advantages of such devices include small dimensions. The use of special spray nozzles allows you to
\end{abstract}

Наукові праці, Том 82, випуск 1 Scientific Works, Volume 82, Issue 1 


\section{Одеська національна академія харчових технологій МОДЕЛЮВАННЯ КОМБІНОВАНИХ ПРОЦЕСІВ ПЕРЕНОСУ. ОПТИМІЗАЦІЯ ОБЛАДНАННЯ І СИСТЕМ}

create a fine splash of water that does not damage the surroundings of speech and equipment. The flexible sleeve of the kit allows you to bypass technological installations that are found on the track. The installation of the overlapping device allows you to interrupt the work at any time and restore it as needed. The cost of extinguishing agent and the installation itself is small. Depending on the conditions of the use of an additional fire faucet, the various characteristics of its components can provide an increase or decrease in the efficiency of its operation. Therefore, a method of determining the characteristics of components of an additional fire faucet for the specific conditions of its operation is proposed. The correct choice of parameters of components will allow, taking into account the hydrodynamic characteristics of the system, ensuring the operation of such devices, with the least economic losses, ensure the successful extinguishing of the fire and reduce losses from it.

Key words: fire faucet, pressure, water flow, sleeve, sprayer.

Вступ. Питання використання внутрішнього протипожежного водопроводу (ВПВ) для гасінні пожеж на підприємствах харчової промисловості на сьогоднішній день $є$ дуже актуальним. Влаштування ВПВ регламентується різними нормативними документами [1, 2]. Вимогами ДБН В.2.5-64:2012 [1] у шафах пожежних кран-комплектів (ПКК) діаметром 50 мм або 65 мм передбачається встановлення додаткових пожежних кран-комплектів, встановлення яких повинно сприяти локалізації загоряння працівниками підприємства та запобігти поширенню вогню до прибуття пожежних підрозділів. В [2] викладені основні вимоги до характеристик складових додаткових ПКК. Відповідно до цих вимог додаткові ПКК комплектуються рукавом (довжина рукава - до 30 м, діаметр рукава - 25 мм або 33 мм, тип рукава - напівжорсткий) та розпорошувачем (діаметр випускного отвору розпорошувача $-4 \div 12$ мм). Використання таких пристроїв, укомплектованих складовими з різними варіантами характеристик, може забезпечити подачу води в кількості, що змінюється в значних межах. А це може створити умови неспроможності ліквідування загоряння за допомогою додаткового ПКК, тобто зробить використання ПКК неефективним, а влаштування ВПВ - недоцільним.

Підвищення ефективності використання ВПВ для гасіння пожеж на підприємствах харчової промисловості можливо за рахунок використання елементів ВПВ з такими характеристиками, вибір яких враховує умови їх використання (пожежне навантаження, конструктивні особливості приміщень, характеристики водопровідної мережі та інше). Метою роботи є дослідження гідродинамічних характеристик елементів ВПВ та розробка способу визначення характеристик складових додаткового пожежного кранкомплекту для конкретних умов його експлуатації, що дозволить вдосконалити характеристики систем внутрішнього водопостачання та підвисить ефективності гасіння пожеж на об'єктах харчової промисловості. Для досягнення поставленої мети необхідно вирішити задачі: визначити вплив змін характеристик складових додаткових ПКК на фактичну кількість води , що можна одержати з них для гасіння пожежі; дослідити достатність фактичної кількості води з ПКК для гасіння пожеж на об'єктах харчової промисловості; запропонувати спосіб вибору характеристик ПКК в залежності від умов їх експлуатації.

Кількість води, яку фактично можливо одержати з ПКК, залежить від декількох характеристик водопровідної мережі до якої ПКК приєднаний, а також від характеристик складових самого ПКК. За вимогами [2] комплектування ПКК відбувається напівжорстким рукавом, але виробники найчастіше комплектують ПКК плоскозгорнутими рукавами довжиною близько 15 м з розпорошувачем, який оснащений пристроєм плавної зміни діаметра випускного отвору, які мають інші значення опору та відповідно впливають на втрати напору в складових ПКК та фактичну кількість води, що з нього можливо одержати.

Експериментальні дослідження. Обговорення результатів. Проведено експериментальне дослідження (з використанням теорії планування експерименту) фактичної кількості води з ПКК для всіх можливих варіантів його оснащення $[3,5,6]$. При проведенні експерименту використовується поліноміальна залежність другого порядку [4], центральний, композиційний, рототабельний уніформ-план. На першому етапі кодуються змінні за стандартними залежностями [4]. При проведенні експерименту використовується стандартна план-матриця експерименту. Для визначення коефіцієнтів при квадратичних членах інформації, отриманої при використанні план-матриці повного факторного експерименту (ПФЕ), проводяться додаткові експерименти у зоряних точках. При цьому зоряне плече $\alpha=1,41421$ у дворівневому експерименті для чотирьох факторів. За результатами експериментів визначені коефіцієнти регресії, які перевірені на значимість отриманням статистичних оцінок дисперсії та порівнянням 3 критичним значенням критерію Ст`юдента. Перевірка адекватності моделі здійснена за критерієм Фішера. Обробка результатів вимірювань дозволила записати моделі витрат води з ПКК:

- для плоскозгорнутих рукавів діаметром 25 мм:

$$
\begin{aligned}
y_{1} & =1,936+0,4973 x_{1}+0,0521 x_{2}+0,6212 x_{3}-0,0421 x_{4}+0,2025 x_{1}^{2}- \\
& -0,1725 x_{2}^{2}-0,16 x_{3}^{2}-0,0725 x_{4}^{2}+0,05 x_{1} x_{2}+0,1375 x_{1} x_{3}- \\
& -0,0187 x_{2} x_{3}+0,0063 x_{2} x_{4}+0,0063 x_{3} x_{4} ;
\end{aligned}
$$

Наукові праці, Том 82, випуск 1 
- для напівжорстких рукавів діаметром 25 мм:

$$
\begin{aligned}
y_{2} & =1,6216+0,5343 x_{1}+0,0706 x_{2}+0,61 x_{3}-0,0335 x_{4}+ \\
& +0,199 x_{1}^{2}-0,0885 x_{2}^{2}-0,1385 x_{3}^{2}-0,0735 x_{4}^{2}+ \\
& +0,1437 x_{1} x_{3}+0,0187 x_{2} x_{3}-0,0063 x_{3} x_{4} ;
\end{aligned}
$$

- для плоскозгорнутих рукавів діаметром 33 мм:

$$
\begin{aligned}
y_{3}= & 3,464+0,6994 x_{1}+0,1141 x_{2}+0,4436 x_{3}-0,0706 x_{4}-0,2025 x_{1}^{2}- \\
& -0,2275 x_{2}^{2}-0,3025 x_{3}^{2}-0,24 x_{4}^{2}+0,0125 x_{1} x_{2}+0,05 x_{1} x_{3}+ \\
& +0,025 x_{1} x_{4}-0,0187 x_{2} x_{3}-0,0187 x_{2} x_{4}+0,0187 x_{3} x_{4} ;
\end{aligned}
$$

- для напівжорстких рукавів діаметром 33 мм:

$$
\begin{aligned}
y_{4} & =3,678+0,8233 x_{1}+0,0716 x_{2}+0,4526 x_{3}-0,0716 x_{4}-0,1862 x_{1}^{2}- \\
& -0,2737 x_{2}^{2}-0,3862 x_{3}^{2}-0,2988 x_{4}^{2}-0,0156 x_{1} x_{2}+0,0781 x_{1} x_{3}+ \\
& +0,0031 x_{1} x_{4}+0,0219 x_{2} x_{3}-0,0156 x_{2} x_{4}+0,0156 x_{3} x_{4} ;
\end{aligned}
$$

де $y_{1}-y_{4}-$ фактичні витрати води з ПКК, л/с; $x_{1}$ - тиск в мережі, який змінюється в межах $(14,6 \div 85,4)$ м; $x_{2}=(20,4 \div 99,6) \%$ - ступінь розгортання рукава; $x_{3}=(4,8 \div 13,2)$ мм - діаметр насадка розпорошувача; $x_{4}=(12,5 \div 29,5)$ м - довжина рукава.

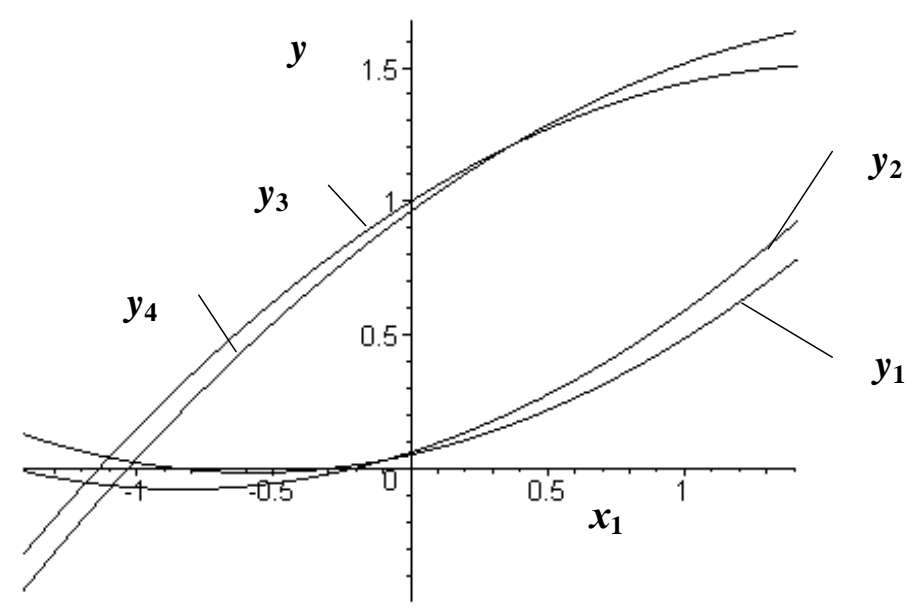

Рис.1. Залежність фактичних витрат води 3 ПКК $y$ від напору в мережі $x_{1}$ при ступені розгортання рукава $x_{2}$ та діаметрі насадка розпорошувача $x_{3}$ на мінімальному рівні, а довжині рукава $x_{4}-$ на максимальному рівні.

Аналіз (1) - (4) показав, що фактичні витрати води з ПКК в значній мірі залежать від тиску в мережі та можуть дорівнювати:

- $(0,13 \div 0,15)$ л/с - при мінімальному тиску в мережі або $(0,04 \div 1,63)$ л/с - при максимальному тиску в мережі (рис. 1) та при найгірших умовах використання ПКК (ступінь розгортання рукава та діаметр насадка розпорошувача найменші, довжина рукава найбільша);

- $(0,33 \div 1,43)$ л/с - при мінімальному тиску в мережі або $(0,79 \div 3,56)$ л/с - при максимальному тиску в мережі (рис. 2) та при найкращих умовах використання ПКК (ступінь розгортання рукава та діаметр насадка розпорошувача найбільші, довжина рукава найменша). 


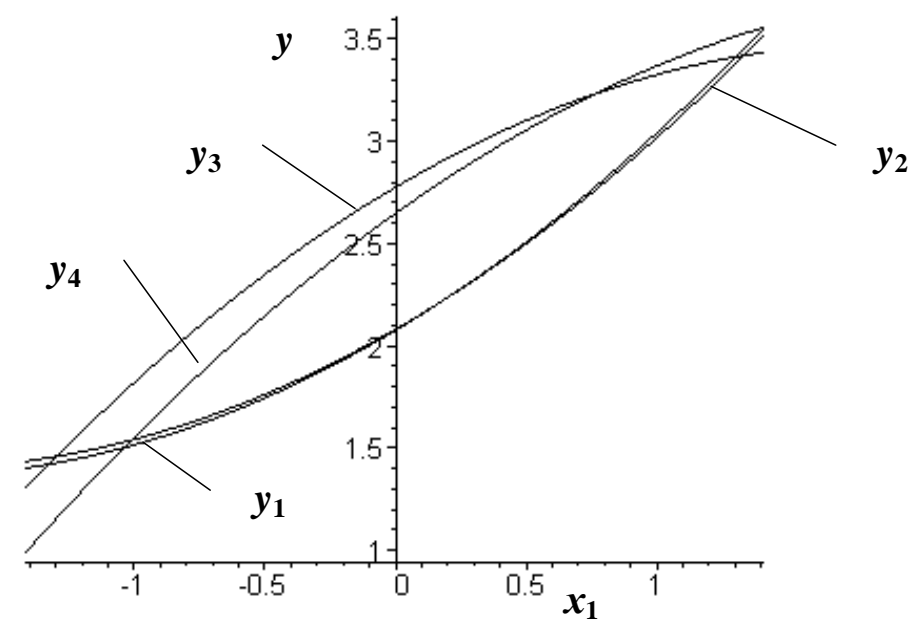

Рис.2. Залежність фактичних витрат води 3 ПКК $y$ від напору в мережі $x_{1}$ при ступені розгортання рукава $x_{2}$ та діаметрі насадка розпорошувача $x_{3}$ на максимальному рівні, а довжині рукава $x_{4}$ - на мінімальному рівні.

Аналізуючи (рис. 1) - (рис. 2) зрозуміло, що характеристики ПКК, які забезпечують витрати води менші, ніж приблизно 0,5 л/с, недоцільні для використання для гасіння пожежі, тому що не зможуть відвести ту кількість теплоти, яка виділяється при пожежі, до того ж за вимогами [1] витрати що приймаються для розрахунку ПКК дорівнюють саме 0,5 л/с.

Дослідження показали, що значний вплив на фактичні витрати води з ПКК має напір в мережі. Також витрати води залежать від діаметра рукава, але вони не завжди збільшуються при збільшенні його діаметру. Таким чином, експериментально визначені фактичні витрати води з ПКК змінюються в межах $(0,04 \div 3,56)$ л/с. Найбільший вплив на величину витрат оказує тиск в мережі, до якій приєднаний ПКК. Для забезпечення необхідної довжини компактної частини струменя, величина тиску повинна бути не менш 6 м, або характеристики складових ПКК повинні забезпечувати найменший опір, тобто мати максимальний діаметр рукава, насадка розпорошувача, мінімальну довжину рукава, що не для всіх варіантів планувань приміщень та розташування технологічного обладнання забезпечить зрошення кожної точки від ПКК.

Тиск в системі внутрішнього водопроводу забезпечується зовнішньою водопровідною мережею та при пожежі може підвищуватися пожежними насосами до 90 м. Гідравлічні розрахунки системи ВПВ показали, що в залежності від віддаленості ПКК від насосів-підвищувачів та умов їх встановлення, тиск в мережі може становити 20, 40 або 60 м. Використовуючи отримані моделі витрат води з ПКК, проведено дослідження діаметра насадка розпорошувача ПКК при фіксованих значеннях довжини рукава 15 м, та середньому значенні ступеню розгортання рукава $50 \%$, для значень витрат води 0,$5 ; 1,5$ та 2,5 л/с, при гарантованому тиску в мережі 20; 40 та 60 м. Дослідження проводились для двох типів рукавів - плоскозгорнутих та напівжорстких. Результати дослідження зведені до табл. 1.

Аналізуючи значення $з$ табл. 1, можна зробити наступні висновки:

- ПКК, приєднані до ВПВ забезпечують подачу нормативних витрат води $(0,5$ л/с) в будь-якій комплектації, але використання розпорошувачів мінімального діаметра насадка недоцільно;

- при встановленні ПКК в будівлях 3 невеликим пожежним навантаженням (необхідні витрати води близько 0,5 л/с) можливо використовувати плоскозгорнуті та напівжорстки рукава діаметром 25 або 33 мм та розпорошувачі мінімального типорозміру незалежно від гарантованого тиску в мережі та інерційності системи виявлення пожежі та оповіщення про неї;

- для будівель підвищеної пожежної безпеки при визначенні характеристик складових ПКК необхідно враховувати фактичний час виявлення пожежі, використовувати обладнання ПКК з мінімальним опором його складових та особливу увагу приділяти забезпеченню надійності роботи насосного обладнання.

Отримані результати надають можливість визначити характеристики складових ПКК, якими обладнуються об'єкти харчової промисловості та які являються елементами системи їх протипожежного захисту. Можливі значення приймаються за умовою, що фактичні витрати води, що одержуються 3 ПКК, укомплектованого складовими з визначеними характеристиками, не менші ніж необхідні витрати води для заданої будівлі. Для визначення характеристик ПКК для конкретного об'єкта харчової промисловості запропонований спосіб, який реалізується в три етапи таким чином. На першому етапі визначають необхідні витрати води для успішного гасіння пожежі в залежності від характеристик пожежного навантаження, що складаються з нижчої теплоти згорання та приведеної масової швидкості вигорання. Крім того враховується час вільного розвитку пожежі та час гасіння пожежі.

Наукові праці, Том 82, випуск 1

Scientific Works, Volume 82, Issue 1 
Визначення діаметра насадка розпорошувача ПКК, присднаного до внутрішнього протипожежного водопроводу будівлі

\begin{tabular}{|c|c|c|c|c|c|c|c|c|c|c|c|}
\hline \multirow[t]{3}{*}{ № } & \multirow{3}{*}{$\begin{array}{c}\text { Діаметр ру- } \\
\text { кава, мм }\end{array}$} & \multirow[t]{3}{*}{ Тип рукава* } & \multicolumn{9}{|c|}{$\begin{array}{c}\text { Діаметр насадка розпорошувача, мм, } \\
\text { при витратах води, л/с } \\
\text { та напорах, м }\end{array}$} \\
\hline & & & \multicolumn{3}{|c|}{$0,5 \pi / \mathrm{c}$} & \multicolumn{3}{|c|}{1,5 л/с } & \multicolumn{3}{|c|}{$2,5 \pi / \mathrm{c}$} \\
\hline & & & $20 \mathrm{M}$ & $40 \mathrm{M}$ & $60 \mathrm{M}$ & $20 \mathrm{M}$ & $40 \mathrm{M}$ & $60 \mathrm{M}$ & $20 \mathrm{M}$ & $40 \mathrm{M}$ & $60 \mathrm{~m}$ \\
\hline 1 & 25 & $\Pi$ & 4 & 4 & 4 & 8 & 8 & 7 & - & - & 12 \\
\hline 2 & 25 & $\mathrm{H}$ & 6 & 5 & 5 & 12 & 10 & 8 & - & - & 14 \\
\hline 3 & 33 & $\Pi$ & 4 & 2 & 2 & 6 & 4 & 3 & - & 7 & 5 \\
\hline 4 & 33 & $\mathrm{H}$ & 4 & 3 & 2 & 6 & 4 & 3 & - & 7 & 5 \\
\hline
\end{tabular}

Примітка: * - тип рукава: п - плоскозгорнутий, н - напівжорсткий.

На другому етапі визначають фактичні витрати води з пожежного кран-комплекту в залежності від характеристик водопровідної мережі, а саме напору в мережі. Також враховуються характеристики пожежного кран-комплекту, а саме характеристики рукава та розпорошувача. До характеристик рукава належать: тип рукава, діаметр рукава, довжина рукава та ступінь розгортання рукава; до характеристик розпорошувача - його діаметр.

На третьому етапі порівнюються необхідні та фактичні витрати води. Спираючись на отриманий результат, формулюють висновок про найефективніший варіант обладнання пожежного кран-комплекту та (або) надають рекомендації щодо умов використання пожежного кран-комплекту.

Висновки. Проведені експериментальні дослідження фактичних витрат води з ПКК. Встановлено, що вони змінюються в межах $(0,04 \div 3,56)$ л/с.

Проведено дослідження характеристик ПКК (діаметра насадка розпорошувача ПКК при фіксованих значеннях довжини рукава та середньому значенні ступеню розгортання рукава) для різних значень витрат води, при гарантованому тиску в мережі. Отримані результати надали можливість визначити характеристики складових ПКК, якими обладнуються об'єкти харчової промисловості та які являються елементами системи їх протипожежного захисту. Для підвищення ефективності використання ПКК доцільно встановлювати їх разом з високоінерційною системою виявлення пожежі та оповіщення про неї, або впливати на кількість та характеристики пожежного навантаження. Виконання відповідних правил проектування та використання ПКК забезпечить їх ефективну роботу в складі системи протипожежного захисту будівлі. Запропоновано спосіб визначення витрат води з ПКК, який дозволяє обгрунтовано обрати обладнання, що здатне забезпечити успішне гасіння пожежі шляхом забезпечення подачі необхідних витрат. При цьому враховується довільна довжина плоскозгорнутих і напівжорстких рукавів, ступень їх розгортання та довільні значення тиску в мережі. Практична цінність запропонованого способу полягає в обгрунтованому виборі обладнання для гасіння пожежі на об'єктах харчової промисловості. При цьому зменшуються витрати води на гасіння пожежі та знижуються матеріальні прями та побічні втрати.

\section{Лiтература}

1. ДБН В.2.5-64:2012. Внутрішній водопровід та каналізація. Частина I. Проектування. Частина II. Будівництво. - Київ: Держбуд України, 2013.- 135 с.

2. ДСТУ 4401-1:2005. Пожежна техніка. Кран-комплекти пожежні. Частина 1. Кран-комплекти пожежні з напівжорсткими рукавами. Загальні вимоги. - Київ: Держспоживстандарт України, 2005. - 22 с.

3. Петухова О.А. Спеціальне водопостачання: підручник [для студ. вищ. навч. закл.] / Петухова О.А., Горносталь С.А., Уваров Ю.В. - Х.: НУЦЗУ, 2013. -248 с.

4. Винарский М.С. Планирование эксперимента в технологических исследованиях / М.С. Винарский, М.В. Лурье. - К.: Техніка, 1975. - 168 с.

5. Петухова О.А. Дослідження характеристик пожежних кран-комплектів / О.А. Петухова, С.А. Горносталь, С.М. Щербак // Проблемы пожарной безопасности. - Х.: НУГЗУ, 2015. - Вып. 37. - С. 154-159.

6. Петухова О.А. Визначення характеристик елементів внутрішнього водопроводу для успішного гасіння пожеж. / О.А. Петухова, С.А. Горносталь // Проблемы пожарной безопасности. - Вып. 41. - 2017. - Харьков. - С. 129-136.

\section{References}

1. DBN V.2.5-64:2012. Vnutrishnij vodoprovid ta kanalizacija. (2012). Kijev: Dergbud Ukrajiny, 135.

2. DSTU 4401-1:2005. Pogegna tehnika. Kran-komplekty pogegni. (2005). Kijev: Dergspogyvstandart Ukrajiny, 22.

3. Petuhova, E.A., Gornostal, S.A., Uvarov, J.V. (2013). Specialne vodopostachannja, Kharkiv, 248.

4. Vinarskiy, M.S., Lurje, M.V. (1975). Planirovanije eksperimenta v tehnologicheskih issledovanijah. Kijev, 168.

5. Gornostal, S.A., Petuhova, E.A., Shcherbak, S.N. (2015). Investigation of the characteristics of fire faucets. Problems of Fire Safety. 37, $154-159$

6. Petuhova, E.A., Gornostal, S.A. (2017). The characterization of the elements of the internal water to successfully extinguish fires. Problems of Fire Safety. 41, 129-136.

Отримано в редакцію 31.05.2018

Прийнято до друку 30.06.2018

Received 31.05.2018

Approved 30.06.2018

Наукові праці, Том 82, випуск 1 